\title{
MUSCULAR HYPERACTIVITY AFTER GENERAL ANAESTHESIA
}

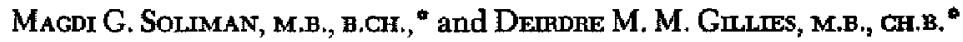

MUSCULAR HYPERACTIVTrY during recovery from general anaesthesia variously termed "spasticity," "shivering," and "shakes," has been described by several authors and has been particularly related to halothane. ${ }^{1-5}$ Several mechanisms have been suggested in explanation including heat loss, ${ }^{1}$ respiratory alkalosis, early recovery of spinal reflex activity, ${ }^{3}$ and sympathetic overactivity. ${ }^{7}$ The reported incidence varies from 5 per cent to 70 per cent ${ }^{3.8}$ and this suggests that perhaps different phenomena are being described.

Having noticed that some patients seemed to show true shivering whilst others showed intense muscular spasticity during emergence from general anaesthesia, this study was designed to try to elucidate whether there were, indeed, two distinct phenomena, what was their incidence, and whether they were specifically related to halothane anaesthesia.

Spasticity was defined as sustained muscular hypertonicity most easily observed in jaw, neck and pectoral muscles, flexors of the upper limbs, and extensors and adductors of the lower limbs. Shivering, on the other hand, was a rhythmic contraction of muscle groups with irregular intermittent periods of relaxation.

\section{Methods}

The recovery of 21.5 unselected patients who had been anaesthetised for a wide variety of surgical procedures, both elective and emergent, was studied. Premedication was given one hour pre-operatively in the usual dosage, using anileridine and promethazine in the large majority. Induction was with thiopentone.

The largest group (125) received halothane as the main agent, 50 received methoxylurane, 20 cyclopropane, and 20 nitrous oxide, meperidine relaxant. Neuromuscular blocking drugs were used when indicated and ventilation controlled as required. Age, sex, operative procedure and duration, environmental temperature and details of anaesthetic technique were recorded.

Rectal or oesophageal temperature was monitored in 83 patients receiving halothane anaesthesia using a YSI Tele-Thermometer. The thermometer was inserted immediately after induction of anaesthesia and readings made throughout operation and recovery until stabilisation of the temperature at a normal level.

In 68 patients arterial blood samples were taken about 15 minutes before the end of the operation and again in the recovery room during the period of spasticity or shivering.

-Department of Anaesthesia, McGill University, and The Queen Elizabeth Hospital of Montreal. 
TABLE I

Incidence or Spasticity with Different Anaesthetic Agents

\begin{tabular}{lccc}
\hline \multicolumn{1}{c}{ Anaesthetic agent } & No. of patients & Spasticity & $\%$ \\
\hline Halothane & 125 & 119 & 95 \\
Methoxyflurane & 50 & 44 & 88 \\
Cyclopropane & 20 & 9 & 85 \\
N. ${ }_{2}$ meperidine relaxant & 20 & 189 & 45 \\
TOTAL: & 215 & & 88 \\
\hline
\end{tabular}

TABLE II

Incidence of Spasticity and Shtvering Related to Various Anaesthetic and Patient Parameters

\begin{tabular}{|c|c|c|c|c|c|c|}
\hline \multicolumn{2}{|c|}{ Factor } & \multirow{2}{*}{$\begin{array}{c}\text { Total } \\
60 \\
90 \\
51 \\
14\end{array}$} & \multirow{2}{*}{$\begin{array}{c}\text { Spasticity } \\
54 \\
80 \\
43 \\
12\end{array}$} & \multirow{2}{*}{$\begin{array}{l}\% \\
90 \\
89 \\
84 \\
86\end{array}$} & \multirow{2}{*}{$\begin{array}{c}\text { Shivering } \\
30 \\
32 \\
16 \\
5\end{array}$} & \multirow{2}{*}{$\begin{array}{l}\% \\
50 \\
35.5 \\
31.4 \\
36\end{array}$} \\
\hline Age & $\begin{array}{r}-30 \\
31-50 \\
51-70 \\
\text { over } 70\end{array}$ & & & & & \\
\hline Sex & $\begin{array}{l}\text { Male } \\
\text { Female }\end{array}$ & $\begin{array}{r}68 \\
147\end{array}$ & $\begin{array}{r}64 \\
125\end{array}$ & $\begin{array}{l}94 \\
85\end{array}$ & $\begin{array}{l}31 \\
52\end{array}$ & $\begin{array}{l}48 \\
35\end{array}$ \\
\hline $\begin{array}{l}\text { Operative } \\
\text { procedure }\end{array}$ & $\begin{array}{l}\text { Extremity } \\
\text { Abdominal } \\
\text { Obstetrical } \\
\text { D \& C } \\
\text { Other }\end{array}$ & $\begin{array}{l}32 \\
91 \\
14 \\
24 \\
54\end{array}$ & $\begin{array}{l}32 \\
75 \\
13 \\
22 \\
47\end{array}$ & $\begin{array}{r}100 \\
82 \\
98 \\
91 \\
87\end{array}$ & $\begin{array}{r}19 \\
28 \\
9 \\
4 \\
28\end{array}$ & $\begin{array}{l}59 \\
31 \\
69 \\
17 \\
42\end{array}$ \\
\hline $\begin{array}{l}\text { Duration of } \\
\text { procedure }\end{array}$ & $\begin{array}{r}-1 \text { hours } \\
1-2 \text { hours } \\
\text { over } 2 \text { hours }\end{array}$ & $\begin{array}{r}107 \\
84 \\
24\end{array}$ & $\begin{array}{l}96 \\
74 \\
10\end{array}$ & $\begin{array}{l}90 \\
88 \\
79\end{array}$ & $\begin{array}{l}37 \\
35 \\
11\end{array}$ & $\begin{array}{l}35 \\
47 \\
45\end{array}$ \\
\hline Premedication & $\begin{array}{l}\text { With } \\
\text { Without }\end{array}$ & $\begin{array}{r}184 \\
31\end{array}$ & $\begin{array}{r}160 \\
29\end{array}$ & $\begin{array}{l}87 \\
93\end{array}$ & $\begin{array}{l}66 \\
17\end{array}$ & $\begin{array}{l}41 \\
55\end{array}$ \\
\hline Relaxant & $\begin{array}{l}\text { None } \\
\text { Curare } \\
\text { S'choline }\end{array}$ & $\begin{array}{r}140 \\
17 \\
38\end{array}$ & $\begin{array}{r}130 \\
15 \\
35\end{array}$ & $\begin{array}{l}92 \\
88 \\
94\end{array}$ & $\begin{array}{r}61 \\
4 \\
16\end{array}$ & $\begin{array}{l}43 \\
23 \\
42\end{array}$ \\
\hline Ventilation & $\begin{array}{l}\text { Spontaneous } \\
\text { Controlled }\end{array}$ & $\begin{array}{r}91 \\
124\end{array}$ & $\begin{array}{r}83 \\
306\end{array}$ & $\begin{array}{l}91 \\
85\end{array}$ & $\begin{array}{l}37 \\
46\end{array}$ & $\begin{array}{l}40 \\
37\end{array}$ \\
\hline Circuit & $\begin{array}{l}\text { Closed } \\
\text { Semi-closed }\end{array}$ & $\begin{array}{r}31 \\
181\end{array}$ & $\begin{array}{r}28 \\
161\end{array}$ & $\begin{array}{l}90 \\
89\end{array}$ & 10 & $\begin{array}{l}32 \\
40\end{array}$ \\
\hline $\begin{array}{l}\text { Blood gases } \\
(68 \text { pts.) }\end{array}$ & $\begin{aligned} \mathrm{pH} & <7.36 \\
7.36 & =7.44 \\
& >7.44\end{aligned}$ & $\begin{array}{l}13 \\
18 \\
37\end{array}$ & $\begin{array}{l}12 \\
18 \\
37\end{array}$ & $\begin{array}{r}92 \\
100 \\
100\end{array}$ & $\begin{array}{r}6 \\
7 \\
17\end{array}$ & $\begin{array}{l}\mathbf{4 6} \\
39 \\
\mathbf{4 6}\end{array}$ \\
\hline
\end{tabular}

"Not including patients who received $\mathrm{N}_{2} \mathrm{O}$, meperidine, curare.

TABLE IH

Incidence of Shivering with Different Anaesthetic Agents

\begin{tabular}{lccc}
\hline \hline \multicolumn{1}{c}{ Anaesthetic agent } & No. of patients & Shivering & $\%$ \\
\hline Halathane & 125 & 52 & 42 \\
Methoxyflurane & 50 & 25 & 50 \\
Cyclopropanc & 20 & 4 & 20 \\
N 0 meperidine relaxant & 20 & $\mathbf{2}$ & 10 \\
TOT $A$ : & 215 & 83 & 39 \\
\hline
\end{tabular}


The blood was analysed on the Astrup Micro-Tonometer (radiometer) apparatus.

The period of returning consciousness was closely observed. This was divided into four stages:

(1) Responding to painful stimuli as determined by the response to a pinch applied to the ear lobe or upper arm;

(2) Responding to simple commands as determined by the ability of the patient to open the eyes or mouth upon request;

(3) Responding to verbal stimuli as determined by the ability of the patient to answer simple questions; and,

(4) Awake-meaning orientated as to time and place.

During this time, muscle tone and reflex activity, in particular ankle clonus and the plantar responses, were constantly assessed. The presence or absence of shivering was noted and peripheral vasoconstriction and pilo-erection looked for.

\section{Results}

The incidence of spasticity after various anaesthetic agents is shown in Table I. It was observed in 88 per cent of patients during emergence from anaesthesia. The incidence, however, was lower ( 45 per cent) in those who had received nitrous oxide-meperidine-curare anaesthesia. This phenomenon was unrelated to age, sex, premedication, operative procedure or duration, use of muscle relaxants, type of ventilation or acid-base status during operation (Table II).

The general incidence of shivering in this series was 39 per cent (Table III). It occurred after all the agents that were used; however, it was less frequent following cyclopropane and nitrous oxide-meperidine-curare anaesthesia.

The changes in core temperature recorded in patients receiving halothane anaesthesia are shown in Figure 1 , and compared with the incidence of shivering. As can be seen, the tendency to shiver increased with increasing interoperative loss of heat.

There was a significant difference in the incidence of spasticity as compared with shivering during emergence from anaesthesia with all the agents studied.

Neither spasticity nor shivering was a feature unique to halothane anaesthesia. The time course of muscular hyperactivity is shown in Figure 2.

Spasticity occurred when the patient had started to respond to painful stimuli and disappeared when the patient was responding to verbal stimuli. Its duration averaged 6-7 minutes and depended on the rate at which the patient recovered consciousness. Ankle clonus could be elicited during the period of spasticity and was most sustained when spasticity was most intense. Extensor plantar responses were present during the early stage of spasticity. Shivering occurred after the patient was responding to simple commands and lasted for an average of 9-10 minutes. The patient would commonly complain of feeling cold and peripheral vasoconstriction and pilo-erection might be present.

The results of arterial blood gas analysis during spasticity and shivering are 


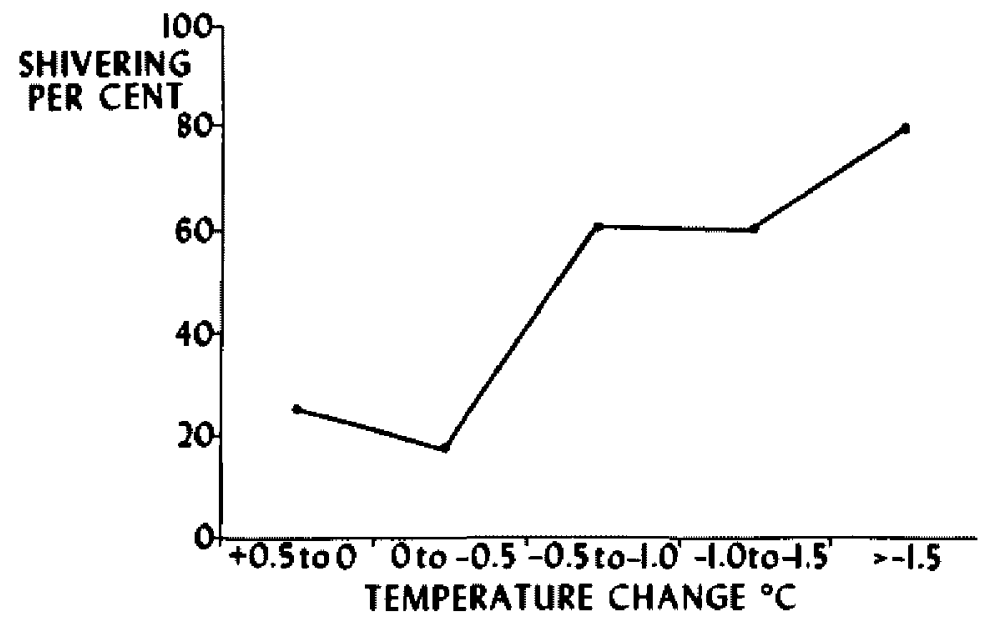

Figune 1. Incidence of shivering during emergence from anaesthesia as compared with intraoperative temperature change.

\section{Time Course of Muscular Hyperactivity}

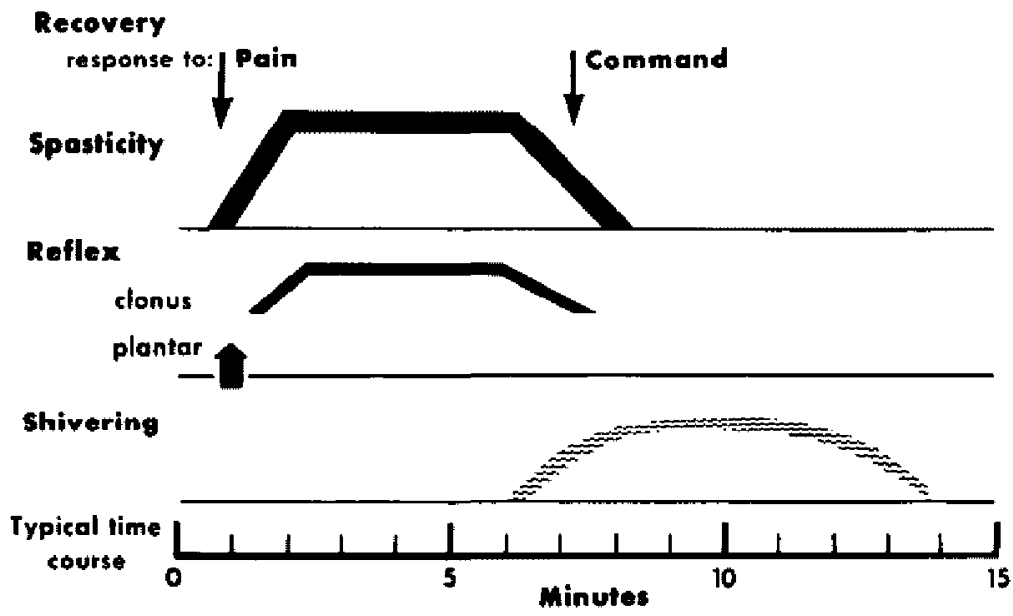

Frcure 2. Time course of muscular hyperactivity during emergence from anaesthesia.

detailed in Table IV. No patient was alkalotic at that time but the large majority showed a mild metabolic acidosis and some also showed a respiratory acidosis.

\section{Discussion}

Two recognizable muscular phenomena seem to occur during emergence from general anaesthesia. The first, spasticity, occurred in nearly all patients and, 
TABLE IV

Arterial Blood Gas Findings during Muscular Hyperactivity AFTER HaLothane ANaEsthesta.

\begin{tabular}{|c|c|c|c|c|}
\hline & $\mathrm{N}$ & Mean & $\begin{array}{c}\text { S.D. } \\
\pm\end{array}$ & Range \\
\hline $\begin{array}{l}\mathrm{pH} \\
\mathrm{Pco}_{2} \\
\mathrm{HCO}_{2} \\
\mathrm{Po}_{2}\end{array}$ & $\begin{array}{l}58 \\
58 \\
58 \\
29\end{array}$ & $\begin{array}{l}7.32 \\
43.1 \\
21.1 \\
77.4\end{array}$ & $\begin{array}{c}0.04 \\
6.75 \\
2.24 \\
11.5\end{array}$ & $\begin{array}{c}7.43-7.23 \\
28.7-68.0 \\
16.2-25.4 \\
56-97\end{array}$ \\
\hline
\end{tabular}

therefore, may be considered as part of emergence. As the brain recovers from general anaesthesia, the reticular formation regains its activity before the higher centres. ${ }^{0}$

The inhibitory cells of the reticular formation are dependent on impulses from the higher centres for their function. The facilitatory cells, on the other hand, have their own spontaneous activity, and so during recovery there is a period of facilitation of the anterior horn cells which results in spasticity. Other upper motor neurone lesion signs may be observed at this time (Figure 3 ).

The lower incidence of spasticity in patients following nitrous oxide-meperidine-curare anaesthesia is probably due to the weaker central depressant effect of these agents.

The possibility that a residual effect of curare is the cause of the lower incidence of hyperactivity in these patients must also be considered. However, curare was also used in conjunction with halothane anaesthesia and in this group the incidence of spasticity was high (Table V).

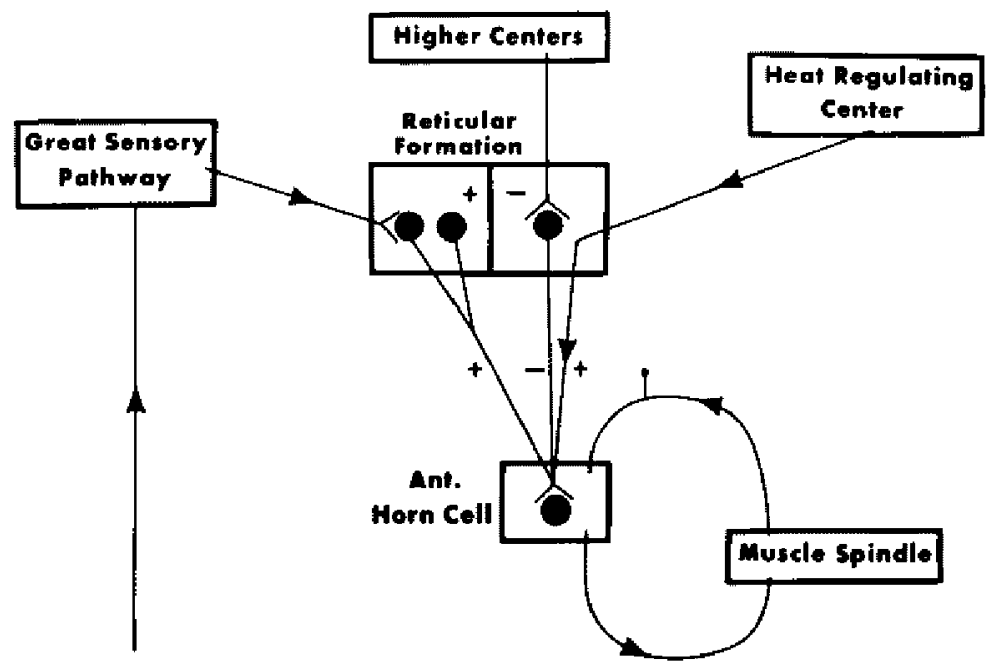

Figune 3. Diagrammatic representation of facilitatory and inhibitory pathways in the central nervous system. 
TABLE $V$

Inciennce of Spasticity and Shivering in Patients Receiving Curare Halothane Anafsthesia as Compared With Curare $\mathrm{N}_{2} \mathrm{O}$ Meperidine

\begin{tabular}{lccccc}
\hline \hline \multicolumn{1}{c}{ Anaesthetic agent } & Total & Spasticity & $\%$ & Shivering & $\%$ \\
\hline Curare and halothane & 17 & 15 & 88 & 4 & 23 \\
Curare $/ \mathrm{N}_{2} \mathrm{O} /$ meperidine & 20 & 9 & 45 & 2 & 10 \\
\hline
\end{tabular}

When compared with spasticity, shivering has a different incidence and time of onset but seems to be largely related to loss of heat: that is to say, it is true thermal shivering.

Temperature was not monitored in the patients receiving either cyclopropane or nitrous oxide-meperidine-curare anaesthesia and we cannot, therefore, explain the lower incidence of shivering in these patients. However, it may be that there is less interoperative heat loss as a result of the use of a closed circuit and an increase in circulating catecholamines.

Shivering also results from facilitation of the anterior horn cell, but it is mediated through the heat regulating centre by heat loss. This eventually results in a critical level of facilitation being reached in the anterior horn cell. Thus shivering is precipitated by the muscle spindle reflex.

In a few patients, the critical level of facilitation may be reached through differential recovery and thus, shivering may be stimulated without heat loss.

\section{SUMMARY}

This study shows that there are two distinct types of muscular hyperactivity which occur during recovery from all types of inhalation anaesthesia. Spasticity, which occurred in the large majority of patients, seemed to be part of the normal recovery pattem. Shivering, on the other hand, occurred in fewer than half the patients and seemed to be largely related to temperature loss during the operative procedure.

Muscular hyperactivity during recovery from general anaesthesia has been reported by various authors, and has been particularly related to halothane anaesthesia. In order to determine the nature of this phenomenon more than 215 patients were closely observed during emergence from general anaesthesia with various inhalation agents.

It appears that there are two distinct types of muscular hyperactivity. The first, spasticity, occurred in the large majority of patients and seemed to be part of the normal recovery pattern. The second was shivering, which occurred in fewer than half the patients and seemed to be largely related to interoperative heat loss. Both forms of hyperactivity occurred with all agents studied.

\section{Rúsumé}

Différents auteurs ont fait part de l'observation d'une hyperactivité musculaire chez les malades au réveil après une anesthésie générale et, cette hyperactivité 
musculaire était reliée particulièrement à Yusage du fluothane. Dans le but de préciser la nature de ce phénomène, nous avons observé de près 215 malades au cours du réveil après une anesthésie générale avec différents agents par inhalation.

Il semble qu'il existe deux sortes d'hyperactivité musculaire. La première est un état de spasmodicité qui apparait chez la plupart des malades et semble faire partie des observations du réveil normal. La deuxième est: le frisson; il apparait chez moins de la moitié des malades et il est vraisemblablement relié à la perte de chaleur préopératoire. Nous avons observé l'existence de ces deux sortes dhyperactivité muculaire avec tous les agents que nous avons étudiés.

\section{REFERENCES}

1. Moin, D.D. \& Dorre, P.M. Halothane and postoperative shivering. Aresthesia and Analgesia 42: 423 (1963).

2. JonEs, H.D. \& MCLAREN, G.A.B. Postoperative shivering and hypoxaemia after halothane, nitrous oxide and oxygen anaesthesia. British Journal of Anaes thesia 37: 35 (1965).

3. BRichard, G. \& Johnstone, M. The effect of methylphenidate (Ritalin) on post-halothane muscular spasticity. British Journal of Anaesthesia 42: 718 (1970).

4. SMrTr, M. et al. Shivering following thiopental sodium and other anesthetic agents. Anesthesiology 16: 655 (1955).

5. Prys-Ronerts, C. Postanesthetic shivering. Clinical Anesthesia. Vol, 3, Chapter 24: 358 (1968).

6. Jonnstone, M. Halothane: The First Five Years (Review). Anesthesiology 22: 591 (1961)

7. STEPHEN, C.R. Postoperative temperature changes. Anaesthesiology 22: 795 (1961).

8. StePHeN, C.R. et al. Evaluation of fluothane for clinical anaesthesia. Canadian Anaesthetists' Society Journal 4: 246 (1957).

9. DAvis, H.S. et al. The effect of halothane (fluothane) on the thalamus and midbrain reticular formation. Anaesthesia 16: 32 (1961). 